\title{
Industrial Relationship Between Worker, Entrepreneur and Government On the Outsourcing Program in PT. Aru Raharja Indonesia
}

\author{
Anandha Budiantoro \\ State University of Jakarta \\ Email: anandhabudiantoro_im13s3@mahasiswa.unj.ac.id \\ Ma'ruf Akbar \\ State University of Jakarta \\ Email: marufakbar@unj.ac.id \\ Wibowo \\ State University of Jakarta \\ Email:wibowo@unj.ac.id
}

\begin{abstract}
This study aims to determine whether the Industrial Relationship Between Worker, Entrepreneur and Government at PT. Aru Raharja Indonesia has achieved its goal. This research method used an evaluative descriptive method. The object of the research was focused on the Industrial relationship between worker, entrepreneur and government on the outsourcing program of PT. Aru Raharja Indonesia.

Data is collected through observatied, documentation studied, and indepth interview. Data analysis used descriptive evaluative techniques, through four stages, namely: data collection, data reduction, data display and conclusion drawing/verification.

The results of the studied found that industrial relationship at the outsourcing program of PT. Aru Raharja Indonesia is classified as moderate. This indicates that the industrial relation to the outsourcing program of PT. Aru Raharja Indonesia still needs to be repaired in its implementation. It can be less effective in the process of communication between worker, entrepreneur and government in the form of coaching, supervision and coordination between the parties involved in the relationship industry.
\end{abstract}

Keywords: Industrial Relationship, Worker, Entrepreneur, Government, Outsourcing Program

Received: 27 July 2019 ;

Accepted: 9 September 2019 ;

Publish; December 2019.

How to Cite:

Budiantoro, A., Akbar, M., \& Wibowo. (2019). Industrial Relationship Between Worker, Entrepreneur and Government On the Outsourcing Program in PT. Aru Raharja Indonesia. International Journal of Human Capital Management, 3 (2), 17-26. https://doi.org/10.21009/IJHCM.03.02.03 


\section{INTRODUCTION}

The progress of a country can be seen from the rapid economic growth of the micro or macro sector to improve the life of the prosperous nation. Indonesia is classified as a developing country. The country's indicators have experienced significant growth in many aspects, especially in agriculture, mining and industrial sector. In an effort to realize the welfare of his people through various economic activities set in the constitution 1945 in article 33 paragraph 1-5, namely that the economy is compiled as a joint venture based on the family principle.

The efforts of the State in the welfare of the people can be done with various economic activities in various fields, one of which is in the field of industry. The industrial field is a feature of emerging economies is one of the branches that absorb a lot of manpower. In this case the government seeks to develop industrial enterprises in improving the nation's economy. In many companies engaged in the industry can absorb a lot of manpower, there is a relationship between workers and entrepreneurs. In this case, various rules governing government relations, workers with entrepreneurs, various rules are enforced in Indonesia in order to regulate this working relationship in the Law No. 13 Year 2003 about employment.

The practice of economic activity in the field of industry resulted in various problems that arise in industrial relationship, especially in the working relationship between employer and worker. The working relationship requires that a work agreement is legally binding on formyl and materil. This aims to ensure a fair and mutually beneficial relationship between entrepreneurs and workers in industrial relationship, especially in the implementation of outsorshing programs. It is given that the unemployment condition in Indonesia according to the central statistic year 2016 amounted to 7.02 million people, 5, 5\% of the total population of Indonesia. There is an increase in the number of levels of a Undergraduate targets of compared with the year 2015 increased from 5.43\% to 6, 22\% (Sawitri, 2016). It is triggered by the difficulty of educated graduates to find jobs and competition conditions to get the job tougher.

The difficulty of getting a job that corresponds to education level ranging from senior high school, Diploma 1, Diploma 2, Diploma 3, and undergraduate causes them to receive all kinds of work despite not matching interests, talents and background education, resulting in low outsorching workers ' wages. Baharuddin (2016:2) stated that through the outsourcing of workers who do not yet have the job can be absorbed, so that the workers get a livelihood source through the giving of wages.

The outsourcing program is part of an industrial relationship study area involving workers, entrepreneurs and governments. The company outsourcing Labor services provider is a company that provides outsourcing labor services for employers company. There are many companies that use the services of outsourcing service provider company. It is an opportunity to be utilized. Providers of outsourcing services are sought to focus on the development of human resource management as an effort to improve the quality of the competitive outsourcing workforce in the industrial field.

Song, (2010) stated that the potential of outsourcing business in Indoesia is quite large ie year 2014 Jour figure of Rp. 17, 4 trillion. According to Song, (2010). That the outsourcing business in Indonesia is growing in the financial sector information and Technology (IT). Jif the trust management company outsourcing manage professionally his business, then the potential profit will increase in the coming years. In the outsourcing business, there are several problems faced with regards to (1) legal protection in working relationships with outsourcing systems, (2) Health and safety in industrial relations, (3) required disputes industry relationship, and (4) employment. These issues, caused by human resource limitation, lack of effective review of the organization of outsourcing program implicates on the process of recruitment and employment of incompetent outsourcing labor.

From the side of the user or employer company find it difficult to conduct communications with management of the outsourcing company as a provider of outsourcing labor services. From the Labor side outsourcing is related to the well-being given by outsorching power provider companies. It appears when the outsourcing workforce that has decades of work, receives a monthly wage that is almost the same as the outsourcing 
workforce that has just the efficacy of working, and has a working period of less than 1 year. Almost all outsourcing workers found also complained about the absence of overtime wages and quality work. This research aims to reply and analyze about the Industrial relations between workers, entrepreneurs and governments in PT. Aru Raharja Indonesia

\section{LITERATURE REVIEW}

\section{a. Outsourcing Program in industrial relations activities}

Understanding industry relations in Law Number 13 of year 2003 on employment Article 1 number 16 mentioned that the industrial relation is a system of relations formed between the perpetrators in the production process of goods and/or services that the administration, workers, and governments based on the values of Pancasila and the Constitution of the Republic of Indonesia in years 1945. According to the Bangun, (2017:29) Industrial relations are inter-stakeholder relations to organizations for Jours purposes in retail and in groups. According to Simanjuntak (2009:67), Industial relations is a relationship to issue a trust related or interested in the production process of goods or services in a company. Khakim (2009:98) states the relationship is the relationship industry between workers, the administration and the Government in the production process.

From the descriptions above, relationships are the industry of worker relationships, the administration and the government in the production process for jours in retail and group purposes in business activities. Implementation of industrial relations is in the production activities between the administration and workers through employment agreements. The liquid outsourcing form of production practices involving workers and personnel in the form of use of workers ' services by the company's trust. According to Carey et.al. (2006) Outsourcing is the transfer of activities from the company of the house which is usually done internally redirected external. Burnes and Antisthenis (2003) assert that outsourcing liquid activities to divert some of the company's activities and decision-making rights to other trust (the company's outsourcing). Silaban suggests that outsourcing adheres to flexibility in the job market in the family of production processes (Rahman, 2016:2).

Many companies use outsourcing services for the development of their information technology (IT), if the company chooses a less precise vendor, then the process of transfer teknonolgi will not run smoothly so it is not Profitable for employers. One of the outsourcing goals is efficiency, so if the employer unknowingly puts the outsourcing worker on the core business sector then it can invite the risk of outsourcing worker status for the law to be Permanent worker employer.

In industrial relationship, outsourcing in Indonesia, according to Djulmiaji (2008:86), there are three things to be aware of, namely: "giving a legal umbrella and legal certainty in the implementation of a working relationship, legal protection especially in the application of working conditions, labor social security, employment continuity and freedom of issue of opinion and association, and the availability of adequate supervisory officers in quantity and quality in order to supervise the regulations intensively In the Outsourcing system field ". Meanwhile, Croush (1992) emphasized that: "Industrial relations must include the sublime values contained in the Sila-please Pancasila considering that Pancasila is the philosophical basis of the nation." Lewin (2010) gives the opinion that occupational safety and health is important for the company, due to the impact of accidents and occupational disease.

Industrial relations is the relationship between all parties who are stuck or concerned about the production process or service in a company. The most interested parties on the company's success and direct dealing with everyday are entrepreneurs or management and workers. In this regard, the Community has an interest, as a supplier of production factors namely goods and services needs of the company and as a consumer society or users of the results of the company. Meanwhile, the government has a direct and indirect interest in the company's growth, such as the source of tax acceptance. So, industrial relations are the relationship between all stakeholders among the management of the company and workers.

\section{b. Industrial Relations Principles}


Simanjuntak (2009) states the principle of industrial relations is based on the equal interests of all elements of the success and continuity of the company. Barrow (2002:292) states that the basic principle of industrial relations is based on the common interest between employers and workers to realize the success of the company. Crouch (1991:262) states that the basic principles of industrial relations refer to the interests of entrepreneurs and workers in functional relationships through a mutually beneficial division of work. Lewin, D. (2010) stated that the basic reference to industrial relations is the relationship of entrepreneurs and workers is a member of the company with a common purpose to achieve mutual benefits. According to Kelly, (2002:209) that in an effort to create company calmness and tranquility work to increase corporate productivity and shared prosperity, it is necessary to establish effective industrial relations.

\section{c. Collective Work Talks}

The joint work agreement is a foothold of employees in achieving achievements which in turn will lead to corporate performance and employee welfare. Millward N., Bryson, A. and Forth, F. (2002) stated that in the work relationship has the potential for differences of opinion that can occur conflicts of interest. Therefore, to overcome the existence of conflict that could harm the parties involved in industrial relationship, it is necessary to have arrangements in the working relationship in the form of joint work agreement. Edwards (2003) has established that joint employment agreements are made with the approval of individual employers and employees. According to Royle and Towers (2002) that the arrangement of collective employment requirements can be in the form of a joint work agreement with the joint work Agreement, which contains a set of terms of employment, rights and obligations of the parties which are the results Negotiations between entrepreneurs, in this case represented by the management of the company and employees who in this case are represented by the Workers Union, as well as listed on the responsible agency in the field of employment. It is contained in article 1 UU Number 13 year 2003 Point 21. The joint work agreement is made through negotiations between the management and the unions.

The above thought is that the joint work agreement is made through negotiations between the management and the unions aiming to guarantee the certainty and protection of the law in the working relationship, so that it can create peace of mind and strive. The validity period of the joint work Agreement is at least 2 (two) years old and may be extended for a period of at least 1 (one) year. The joint work Agreement is an instrument used for the operation of industrial relations, where other means are unions, entrepreneur organizations, bipartite cooperation agencies, tripartite cooperation agencies, regulations Regulations, industrial relations dispute resolution institutions. According to the conditions,

The subsequent making of the joint Employment Agreement can be initiated at least 3 (three) months prior to the expiry of the applicable joint work agreement. In case of negotiations when not reaching an agreement, the ongoing joint work agreement remains in effect for at least 1 (one) year. Thus, the process of creating a shared work agreement does not take a long and protracted time until a dead lock resulting in the absence of legal certainty.

\section{METHODOLOGY}

The method used in this study is evaluative descriptive method. The object of the research was focused on the Industrial relations between workers, entrepreneurs and governments at PT. Aru Raharja Indonesia. Data is collected through observatied, documentation studied, and indepth interview. Data analysis used descriptive evaluative techniques, through four stages, namely: data collection, data reduction, data display and conclusion drawing/verification.

Analysis of data in this study using CIPP model. The evaluation Model was developed by Wirawan which is used as a process of depicting, obtaining, providing useful information to assess the necessary alternatives in order to make decisions (Wirawan, 2012:92). Stufflebeam reveals that the CIPP model can be used by internal evaluators, either by the 
team or individually as measured through the four phases: Conteks, input, process, and product.

According to Stufflebeam. and Coryn, (2014) The CIPP model includes (1) "An evaluator employs a context evaluation to assess needs, problems, assets, and opportunities within a defined environment. Needs include those things that are necessary or useful for fulfilling a defensible purpose. (2) "essentially, an input evaluation should involve identifying and rating relevant approaches (including associated equipment and materials) and assist decesion makers in preapering the chosen approach for execution. An evaluator should also search through the client enviromental for political barriers, financial or legal constraints, and potentially available resource ". (3) "A process evaluation includes an ongoing check on a plane's implementation and documentation of the Associates Process" and (4) "The purpose of a product evaluation is to measure, interpret, and judge an enterprione's outcome. Feed back about outcomes is important both during an activity cycle and at its conclusion. Product evaluator should assess intended and uninteded outcomes and positive and negative outcomes."

To measure the achievement level of evaluation criteria used reference data benchmark of ordinal-scale categories,. The use of ordinal scale 1-3 describes the low with a score less than $<50 \%$, Scale 2 describes the moderate score achieved between $50-89 \%$, and the scale 3 describes the height with a score of $>90 \%$. Schemes of the assessment mechanism used are described as follows:

Table 1 Decryption Rating

\begin{tabular}{|c|l|l|}
\hline $\begin{array}{l}\text { Scale } \\
\text { Scoring }\end{array}$ & Rating & Description \\
\hline 1 & Low & $\begin{array}{l}\text { criteria are not met under } \\
50 \% \text { of the number of } \\
\text { criteria grains. }\end{array}$ \\
\hline 2 & Moderate & $\begin{array}{l}\text { evaluation criteria are } \\
\text { partially fulfilled, 50-89\% } \\
\text { of the number of criteria }\end{array}$ \\
\hline 3 & High & $\begin{array}{l}\text { evaluation criteria met } \\
\text { more > 90\% of the } \\
\text { number of criteria }\end{array}$ \\
\hline
\end{tabular}

Source: Mulyatiningsih, E. (2014: 35). Metode Penelitian Terapan

Bidang Pendidikan.

\section{RESULT AND DISCUSSION}

\section{A. Research Results}

1. The legal foundation of industrial relations between workers and entrepreneurs on the outsourcing program of PT. Aru Raharja Indonesia.

The legal foundation of industrial relations between workers and entrepreneurs on the outsourcing program of PT. Aru Raharja Indonesia refers to the Law number 13 year 2003 about employment and regulation of the Minister of Labour and transmigration of the Republic of Indonesia ( Number 19 year 2012) about the terms of submission of some work execution to another company. The legislation is not documented in the company's important documents, with the aim to help the parent company to focus on what the core business has achieved, even in practice the target Outsourcing programs are not yet achievable for the implementation of the outsourcing program strategies owned by PT. Aru Raharja only refers to the target creation of good service and the creation of the company's organizational atmosphere conducive.

2. Management, Industrial Relations Between Workers and Entrepreneurs at PT. Aru Raharja Indonesia 
Management, industrial relations between workers and entrepreneurs at PT. Aru Raharja Indonesia, conducted through operational activities under the authority of Operations director assisted by operations managers, assistant operations managers and staff Operational. Financial managers, human resources, and the general under the direct control of the President director but the duties and functions of the financial managers, human resources, and general are only limited to the time of the recruitment process and the selection of labor outsourcing, placement, Wages, employment and termination of employment. Coaching, communication, supervision of outsourcing programs under the control of the Directorate of Operations, but in the reality of communication between entrepreneurs and Governments in the form of reports of manpower activities assessed still low, so implication on Employment supervision, particularly in relation to safety, health and welfare of workers. Similarly, the communication between entrepreneurs and labor manpower in the form of coordination Dninilai is still not optimal.

To achieve target outsourcing program, PT. Aru Raharja Indonesia has three outsourcing strategy program that is 1.) maintaining good relations with PT. Jasa Raharja 2.) Always strive to provide the best service 3.) Conducting interactions/socialization with partners in a proforsional basis by officers and staff in accordance with their duties and authorities.

PT. Aru Raharja Indonesia's Outsourcing program plan is complete with target and target income, but not yet have Standar Operational Procedur book, it implicates the existence of error procedures during implementation of the program. Recruitment and outsourcing workforce selection of $90 \%$ applicants derived from the internal recommendation of parent company Group, the selection process is not strict. The process of recruitment and selection does not involve the psychotest only a short interview conducted in the branch office of Jasa Raharja implemented by the Management of branch office, head office of PT. Aru Raharja only only accept the proposal. This causes the quality of work of the outsourcing workforce can not be known and accountable by the party of PT. Aru Raharja Indonesi, because the management does not participate actively during the process of recruitment and selection directly against Prospective outsourcing workforce applicants.

Industrial relations between entrepreneurs and workers in the form of cooperation agreements on procurement of supporting services between PT. Jasa Raharja (Persero) with PT. Aru Raharja Each has contained the rights and obligations of each Party as well as the details of the work and The required costs, settlement of disputes and the term of cooperation agreements signed by both parties. Of the 11 article of the work, the component of overtime wages is not entered into the cooperation agreement of the supporting services procurement. Source of funds in Industrial relations activities for the implementation of the outsourcing program in PT. Aru Raharja Indonseia is assessed as insufficient, although the employer has first paid the value of the employment agreement of the Service procurement Support.

\section{Placement, construction of the Outsourcing Program implementation}

Outsourcing manpower placement, relies heavily on the needs of the head office/branch of PT. Jasa Raharja. PT. Aru Raharja Live to approve the proposal, because the placement is a proposal from the head office/branch of PT. Jasa Raharja that requires outsourcing labor. recruitment and selection is done by the branch office of PT. Jasa Raharja, because the management of PT. Jasa Raharja not necessarily understand about the competencies needed to carry out a job from the outsourcing workforce such as security guards, night guard, interpreter and cleaning service. New outsourcing workforce placement does not necessarily match the criteria of competency that must have prospective outsourcing workforce to be able to work on a particular job.

The outsourcing manpower coaching is done by the head office/branch of PT. Jasa Raharja. Once a year the management of PT. Aru Raharja conducts development throughout Indonesia through routine socialization programs, ranging from President director, operational director, operational manager, finance manager, Human resources, and general. The function of coaching by the regional coordinator is the outsourcing workforce appointed 
by the management is less functional because basically they are also an outsourcing workforce that concurrently becomes the coordinator of the region, So it is sometimes less respected by fellow outsourcing workforce peers.

The activity of outsourcing program in PT. Aru Raharja has been in accordance with the prevailing law and the the number 19 years 2012 on the terms of supporting services work. Work of supporting services that have been implemented by PT. Aru Raharja covers the field of hygiene services, security services, and transportation services. But in activity the implementation of outsourcing program still there is a deficiency especially related to the performance of outsourcing workforce is a matter of discipline level.

Internal performance supervision of outsourcing manpower is more done by employers company namely PT. Jasa Raharja compared from the party of PT. Aru Raharja itself, supervision from external parties that is the institution authorized in the affairs Tribe of Trasmigration is not there. This is because the management of PT. Aru Raharja has long been not conducting communication and coordination with the employment supervisor. The outsourcing workforce performance assessment was not implemented, consequently the performance of the outsourcing workforce could not be measurable. The lack of performance assessments caused them to be less productive, as they did not know what performance they had to accomplish. An avid and lazy outsourcing workforce earns the same amount of wage rewards.

\section{Results and benefits of Outsourcing Program at PT. Aru Raharja Indonesia}

Results and benefits of industrial relations through the outsourcing program at PT. Aru Raharja Indonesia as the outsourcing Labor services company, is the inability to management PT. Aru Raharja to achieve the target of growth of the number of workers Outsourcing by 5\% annually. Achievement of target growth of average outsourcing workforce still revolves around 3\%. This is the result of PT. Aru Raharja not looking for new clients outside PT. Jasa Raharja (Persero) so that the growth of the outsourcing workforce has stagnated in the number $3 \%$.

The results and benefits of outsourcing programs for employers is user, not yet helped enough with the presence of outsourcing workforce that helps and serves them professionally and disciplined. This causes them not to be fully focused on the core of their business. They are sometimes still concerned with issues related to coaching activities and outsourcing workforce supervision.

Table 1 Decryption Rating of Research Results

\begin{tabular}{|l|l|l|}
\hline Number & \multicolumn{1}{|c|}{ Component } & \multicolumn{1}{c|}{ Value } \\
\hline 1 & $\begin{array}{l}\text { He legal basis of industrial } \\
\text { relations between workers and } \\
\text { entrepreneurs on the } \\
\text { outsourcing Program of PT. } \\
\text { Aru Raharja Indonesia }\end{array}$ & High (100) \\
\hline 2 & $\begin{array}{l}\text { Management, industrial } \\
\text { relations between workers and } \\
\text { entrepreneurs at PT. Aru } \\
\text { Raharja Indonesia }\end{array}$ & $\begin{array}{l}\text { Moderate } \\
(69,23)\end{array}$ \\
\hline 3 & $\begin{array}{l}\text { placement, construction of the } \\
\text { Outsourcing Program } \\
\text { implementation a }\end{array}$ & $\begin{array}{l}\text { Moderate } \\
(64,70)\end{array}$ \\
\hline 4 & $\begin{array}{l}\text { Results and benefits of } \\
\text { Outsourcing Program at PT. } \\
\text { Aru Raharja Indonesia }\end{array}$ & $\begin{array}{l}\text { Low } \\
(33,33)\end{array}$ \\
\hline
\end{tabular}




$\begin{aligned} & \text { Way of judgment } \\ & \text { Component value }=\frac{\text { Number of values of each component }}{\text { Number of components of the Program }}\end{aligned}$
Component value : $\frac{267,26}{4}=66,85 \%$ (moderate criteria).

From the results of the assessment of industrial relations in the outsourcing program, it can be stated that industrial relations in the outsourcing program of PT. Aru Raharja Indonesia is classified as moderate with a final value of $65.81 \%$. This indicates that the industrial relation to the outsourcing program of PT. Aru Raharja Indonesia still needs to be repaired in its implementation, especially in relation to management, industrial relations between workers and entrepreneurs, placement, construction Outsourcing program implementation and the results and benefits of the Outsourcing Program. It can be less effective in the process of communication between workers, entrepreneurs and government in the form of coaching, supervision and coordination between the parties involved in the relationship industry.

\section{B. Discussions}

Based on the results of research findings using the method of context, input, process, and product it shows that the legal basis of industrial relations in the outsourcing program includes program objectives and program objectives are assessed very effective program objectives Outsourcing in PT. Aru Raharja in the industry relationship activities is to help the parent company in handling the jobs that are non core business. Khalili et. Al. (2017) explained that many companies use outsourcing services because they want to focus on what is the core business businesses. Yasar, (2010:17).

Industry relations activities through the outsourcing program in PT. Aru Raharja Indonesia seen from the organizational structure, management, strategy, program planning, standard operational procedures, readiness of human resources, recruitment, labor selection outsourcing, cooperation agreements, procurement of supporting services, readiness of facilities and infrastructure supporting the outsourcing program, the availability of funding sources of outsourcing program is assessed quite effective with a score of $69.23 \%$. Therefore, to achieve the input implementation of effective outsourcing program need to be done repair through the input components above.

PT. Aru Raharja in the organizational structure adopted divisional Departementalization, but in its implementation does not have SOP book as a guide/guidance implementation of outsourcing program, outsourcing program has contributed by $75 \%$ For the company's overall income. Arnina P, et. Al. (2011:32) SOP has the principle of drafting and implementation in order to be easily understood and implemented well by all elements in the organization. Hamlen and Thuraisingham stated that in the era of globalization has resulted in data outsourcing, software, and hardware and various services.

Implementation of industry relationship outsourcing programs include: placement, outsourcing workforce Coaching, worker performance appraisal, worker training, communication and supervision expressed moderately moderate with a score of $64.70 \%$. Therefore, to achieve the input implementation of effective outsourcing program need to be done repair through the components of the process above. According to Yasar that the outsourcing workforce placement in the user's company was handed over to the power company (Yasar, 2010:70).

Communication in the activities of industry relations in the outsourcing program between the management of PT. Jasa Raharja and management of PT. Aru Raharja less running smoothly. This is because the management of PT. Aru Raharja is considered less proactive in conducting communication. Halim et al. (2018). Concerned that the variable quality of partnerships such as trust, business understanding, and communication have had a significant positive impact on the success of industrial relations in the outsourcing program. 
Supervision from external to the industry relationship in the outsourcing program to be in PT. Aru Raharja, the service is carried out by the manpower and transmigration Office of South Jakarta. The limited number of human resources supervisor Manpower owned by the South Jakarta Tribe of Trasmigration is becoming the side inhibitor to supervise the implementation of outsourcing program in the company's service providers Outsourcing.

The results and benefits of the program for outsourcing workforce are stated to be less effective with a score of $33.33 \%$. Therefore, in order to realize the mutually beneficial industrial relations between workers and entrepreneurs, it is necessary to improve the effective communication between workers, entrepreneurs and governments through the development, coaching and coordination. As according to Hamlen W, K. and Thuraisingham, B. (2012). That consumers who feel dissatisfied are likely to change their purchase behavior by making a move to other brands Mondy reveals that employee equity or employee-equity will be realized, when the individuals who run the work The same receives payment according to factors such as performance level or seniority (Mondy, 2008:6).

\section{CONCLUSION}

Based on the results of research findings on the implementation of the outsourcing program in PT. Aru Raharja Accordingly, can be formulated the following conclusions:

Legal basis of industry relations at the outsourcing program in accordance with law Number 13 year of 2003 concerning employment and regulation of the Minister of Manpower and Transmigration of the Republic of Indonesia (Perconquertrans RI) Number 19 year 2012 about the terms Submission of some work to another company.

Activities of industrial relations through the outsourcing program in PT. Aru Raharja Indonesia seen from the organizational structure, management, strategy, program planning, standard operational procedures, readiness human resources, recruitment, labor selection outsourcing, cooperation agreements, procurement of supporting services, readiness of facilities and infrastructure support outsourcing program, the availability of funding sources of outsourcing program is assessed quite effective. Therefore, to achieve the input implementation of effective outsourcing program need to be done repair through the input components above.

Implementation of industry relations outsourcing programs include: placement, outsourcing workforce coaching, employee performance appraisal, worker training, communication and supervision expressed moderately moderate. Therefore, to achieve the input implementation of effective outsourcing program need to be done repair through the components of the process above.

Results and benefits of industrial relations on outsourcing programs among workers and entrepreneurs expressed less effective. Therefore, to achieve a mutually beneficial industry relationship in the outsourcing program needs to be carried out improvement of the company Antra workers, entrepreneurs and governments, through coordination, coaching and supervision

Based on the above conclusion, overall it can be stated that the industrial relation in the outsourcing program of PT. Aru Raharja Indonesia is classified as moderate. This indicates that the industrial relation to the outsourcing program of PT. Aru Raharja Indonesia still needs to be repaired in its implementation. It can be less effective in the process of communication between workers, entrepreneurs and government in the form of coaching, supervision and coordination between the parties involved in the relationship industry.

The researcher would like to thank the leaders and staff of the PT Aru Rajharja Indonesia who had helped in the completion of this research. 


\section{REFERENCES}

Arnina P. dkk., (2016). Langkah-langkah efektif menyusun SOP. Jakarta: Depok, Huta Publisher.

Baharuddin, R. (2016). Outsourcing, menyingkap hegemonik dalam praktek ketenagakerjaan. Surakarta: Oase Pustaka.

Bangun, W. (2017) Manajemen SDM Hubungan Industrial, Jakarta: Erlangga

Barrow, C. (2002) Industrial Relations Law, Britain, Cavendish Publishing Limited.

Burnes, B. and Antisthenis A. (2003),"Outsourcing: a public-private sector comparison", Supply Chain, Management: An International Journal, Vol. 8 Iss 4

Carey, P. et.al, (2006). Internal audit outsourcing in Australia, International Journal, Compilation, AFAANZ, Accounting and Finance.

Croush, Collin (1992) Industrial Relations and European State Traditions, New York: Oxford University Press

Djulmiaji, (2008) Perjanjian Kerja Edisi Revisi, Jakarta: Sinar Grafika

Edwards, P. (2003) Industrial Relations: Theoru and Practice, Hongkong, Balcwell

Halim et. al. (2014). Human Resource Outsourcing Success: Leveraging on Partnership and Service

Quality.114.SAGEandOpenAccesspagehttp://journals.sagepub.com/doi/abs/10.1177/ 2158244014545475. diakses 20 Februari 2018.

Hamlen W, K. and Thuraisingham, B. (2012). Data security services, solutions and standards for outsourcing. Elsevier journal. The University of Texas at Dallas, United States. 2012.

Kelly, J. (2002) Rethinking Industrial Relations, Mobilization, collectivism and long waves, Canada: Routledge, New York: Howard House

Khakim, A. (2009) Dasar-Dasar Hukum Ketenagakerjaan di Indonesia, Bandung: Citra Aditya Bakti

Khalili et. al. (2014). Investigating the relationship between outsourcing and performance based on Balanced Score Card . Case study: Ilam Post Office). Journal of data Envelopment Analysis and Decision Science. Vol. 2014.

Lewin, D. (2010) Advences In Industrial And Labor Relations, New York: Howard House

Millward N., Bryson, A. and Forth, F. (2002) All Change at Work? British employment relations 1980-1998, as portrayed by the Workplace Industrial Relations Survey series, New YorK: Routledge.

Mulyatiningsih, E. (2014). Metode Penelitian Terapan Bidang Pendidikan. Bandung: Alfabeta.

Mondy, R. W. (2008). Manajemen Sumber Daya Manusia. Edisi Kesepuluh Jilid 1 . Jakarta: Penerbit Erlangga.

Rahman, B. (2016). Outsourcing. Menyingkap Relasi Hegemonik Dalam praktek ketenagakerjaan. Surakarta: Penerbit Oase Pustaka.

Royle, T and Towers, B. (2002) Labour Relations in the Global Fast-Food Industry, London: Financial Times

Sawitri, A. A. (2016). "Pengangguran Terbuka di Indonesia Capai 7,02 Juta Orang,.

Simanjuntak, P. J. (2009) Manajemen Hubungan Industrial, Jakarta: Jala Permata Aksara,

Song, M. H. and Wong, F. S. (2010). Understanding Customer Satisfaction in the IT Outsourcing Environment: A Classification of Quality Attributes. Journal of Outsourcing and Organizational InformatioManagement. IBIMAPublisihing. Vol.2010.

Stufflebeam. L. D. and Coryn, L.S.C. (2014). Evaluation Theory, Models and Aplication. USA: Jossey Bass.

Yasar, I. (2008). Sukses Implementasi Outsourcing. Jakarta: PPM Manajemen. 